Rev. Int. Contam. Ambie. 33 (Especial Biotecnología e ingeniería ambiental) 143-150, 2017

DOI: 10.20937/RICA.2017.33.esp01.13

\title{
ISOLATION AND SCREENING OF BACTERIA FROM Zea mays PLANT GROWTH PROMOTERS
}

\author{
Jeiry TORIBIO-JIMÉNEZ ${ }^{1}$, Miguel Ángel RODRÍGUEZ-BARRERA ${ }^{1}$, \\ Giovanni HERNÁNDEZ-FLORES ${ }^{2}$, Jesús Carlos RUVALCABA-LEDEZMA ${ }^{3}$, \\ Mildred CASTELLANOS-ESCAMILLA ${ }^{4}$ and Yanet ROMERO-RAMÍREZ ${ }^{1, *}$
}

\footnotetext{
${ }^{1}$ Laboratorio de Microbiología Molecular y Biotecnología Ambiental, Unidad Académica de Ciencias Químico Biológicas, Universidad Autónoma de Guerrero. Avenida Lázaro Cárdenas sin número, Ciudad Universitaria, Chilpancingo, Guerrero, México, C. P. 39070

${ }^{2}$ Consejo Nacional de Ciencia y Tecnología-Unidad Académica de Ciencias de la Tierra, Universidad Autónoma de Guerrero. Ex Hacienda San Juan Bautista sin número, Taxco el Viejo, Guerrero, México, C. P. 40323

${ }^{3}$ Instituto de Ciencias de la Salud, Universidad Autónoma del Estado de Hidalgo. Ex Hacienda la Concepción sin número, carretera Pachuca - Tilcuautla, Tilcuautla, Hidalgo, Mexico, C. P. 42060

${ }^{4}$ Biochemistry and Molecular Biology Department, University of Calgary. 2500 University Drive NW, AB T2N 1N4, Calgary, Canada

*Corresponding author: yromero@uagro.mx
}

(Received March 2016; accepted August 2016)

Key words: corn, biofertilizer, rhizobacteria, rhizosphere

\begin{abstract}
Plant growth promoting rhizobacteria is a beneficial microbe colonizing plant roots, which enhances crop productivity and offers an attractive way to replace chemical fertilizers, pesticides, and supplements. In Mexico, the corn (Zea mays L.) is an important annual gramineae crop with a high volume of global production because of the favorable environmental and socioeconomic situation. In this study the isolation of new strains of bacteria under different environmental conditions will enable further research avenues to better use the capacities of root-colonizing bacteria in agricultural production systems. The strains isolates were analyzed for five plant-growth-promoting attributes: N fixation, solubilization of phosphate, production of auxins, siderophores and gibberellins. The identification of bacterial isolates was determined by biochemical assays and VITEK2 Compact (bioMérieux). A total of 143 morphologically distinct rhizobacteria from corn crops of three communities of Guerrero, Mexico, were isolated, and 54 effective multi trait rhizobacteria were found. It was determined that the bacterial isolates are related to Pseudomonas, Enterobacter, Serratia, Pantoea, Staphylococcus, Klebsiella, Burkholderia, Salmonella, Proteus, Acinetobacter, Citrobacter and Streptoccoccus genus. This collection represents the first bank of multi trait activity in Mexico, and it will contribute to future studies as biomolecules for promoting early emergence and growth of the seeds.
\end{abstract}

Palabras clave: maíz, biofertilizante, rizobacteria, rizosfera 


\section{RESUMEN}

Las rizobacterias promotoras del crecimiento vegetal, son microorganismos benéficos que colonizan las raíces de las plantas para mejorar la productividad de los cultivos y ofrecen una forma atractiva para reemplazar los fertilizantes químicos, plaguicidas y suplementos. En México, el maíz (Zea mays L) es un importante cultivo de gramínea anual con grandes volúmenes de producción global debido a las condiciones ambientales y socioeconómicas favorables. En este trabajo se aislaron nuevas cepas de bacterias bajo diferentes condiciones ambientales que permitirán investigaciones futuras sobre el uso de las capacidades de las bacterias que colonizan la raíz en los sistemas de producción agrícola. A las cepas aisladas se les analizaron cinco capacidades de promoción del crecimiento vegetal: fijación de nitrógeno, solubilización de fosfatos, producción de auxinas, sideróforos y giberelinas. La identificación de las bacterias aisladas se hizo por pruebas bioquímicas y el sistema VITEK2 (bioMérieux). Un total de 143 rizobacterias morfológicamente distintas se aislaron de cultivos de maíz de tres comunidades de Guerrero, México y se encontraron 54 de ellas con múltiples capacidades. Se determinó que los aislados bacterianos se relacionan con los géneros Pseudomonas, Enterobacter, Serratia, Pantoea, Staphylococcus, Klebsiella, Burkholderia, Salmonella, Proteus, Acinetobacter, Citrobacter y Streptoccoccus. Esta colección representa el primer banco de bacterias con múltiples capacidades en México y contribuirá a futuros estudios de biomoléculas para promover el crecimiento temprano de las semillas de las plantas.

\section{INTRODUCTION}

The rhizosphere is inhabited by large numbers of microorganisms known as plant-growth promotingrhizobacteria (PGPR) (Di Salvo et al. 2014, Gupta et al. 2014) that significantly stimulate plant growth through direct or indirect mechanisms. The direct mechanisms include biofertilization, stimulation of root growth, rhizo-remediation and plant stress control (Labra-Cardón et al. 2012, Vacheron et al. 2013). Indirect mechanisms primarily involve biological control comprised of antibiosis, induction of systemic resistance and competition for nutrition and niches (Lugtenberg et al. 2009). These mechanisms can be active simultaneously or independently at different stages of plant growth. Activities that promote these mechanisms are phosphate solubilization, biological $\mathrm{N}$ fixation, siderophores production, and phytohormone production like indole-3-acetic acid and auxins, which are regulators that profoundly influence plant growth (Bharucha et al. 2013).

PGPR includes a wide variety of genera and species, i.e. Rhizobium (Yadegari et al. 2008, Schwachtje et al. 2011, López-Ortiz et al. 2012), Frankia, Azotobacter, Pseudomonas (Shim et al. 2014, ZuluetaRodriguez et al. 2014), Beijerinckia, Alcalisens, Arthobacter, Burkholderia (Poupin et al. 2013), Bacillus (Lopez-Bucio et al. 2007), Serratia and Azospirillum (Di Salvo et al. 2014) and other similar microorganisms commonly used as crop inoculants of agricultural interest. Most of these bacteria produce physiologically active substances that foment seed germination, growth acceleration, and increased crop yield, improving plant defenses against pathogens.

Corn (Zea mays L.) is a food rich in nutrients, however it needs an abundant supply of sunlight to grow. In the southern hemisphere it is sown from August to September and harvested in March, April or May, whereas in the northern hemisphere it is sown from April to May and harvested in September or October.

Mexico is the worldwide top producer, it is estimated 880 Million of tons per year, covering an area of 841677 ha just in Guerrero state (SAGARPASIAP 2012). Furthermore, Guerrero is well known for the production of other products, however the continued use of chemical fertilizers and manures for enhancing soil fertility and crop productivity often results in unexpected harmful environmental effects (Romero-Ramírez et al. 2016). The latter include leaching of nitrate into ground water, surface run-off of phosphorus and nitrogen, and eutrophication of aquatic ecosystems. Integrated nutrient management systems are needed to maintain agricultural productivity and to protect the environment. Microbial inoculants are promising components of such management systems (Adesemoye et al. 2009). Studies with microbial inoculants and nutrients have demonstrated that some inoculants can improve plant uptake of nutrients. They have also been used for heavy metal phytoremediation or for increasing plant resistance to biotic and abiotic stress factors purposes (Dimkpa et al. 2009, Yang et al. 2009, Moreira 
et al. 2014, Hernández-Flores et al. 2015a,b), thereby decreasing the use efficiency of chemical fertilizers.

The aim of this work was focused on the isolation and the screening of new strains from corn crops under different socio-environmental context, these strains should have plant growth promoting multi-traits. So, this study is interested in gathering information about new strains with possible effects of a PGPR on plant development.

\section{MATERIALS AND METHODS}

\section{Isolation of rhizobacterial strains, media and growing conditions}

Fifteen samples of rhizosphere and root from creole and ungraded corn crop were collected in duplicate in August 2013. The samples were taken from experimental farms located at one site in Sabanillas $\left(17^{\circ} 00^{\prime} 52^{\prime \prime} \mathrm{N}\right.$; $99^{\circ} 42^{\prime} 42^{\prime}$ ' W), two sites in Tlacoapa $\left(17^{\circ} 04^{\prime} 14^{\prime \prime}-17^{\circ} 21^{\prime} 05^{\prime \prime} \mathrm{N}\right.$; $\left.98^{\circ} 40^{\prime} 52^{\prime \prime}-98^{\circ} 53^{\prime} 09^{\prime \prime} \mathrm{W}\right)$

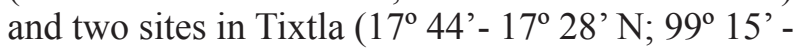
$99^{\circ} 28^{\prime} \mathrm{W}$ ), in Guerrero state, southern Mexico. The roots were taken from the surface and sterilized by rinsing them with $95 \%$ ethanol for $15 \mathrm{~s}$, followed by a $0.1 \% \mathrm{HgCl}_{2}$ solution for $3-5 \mathrm{~min}$. The sterilized roots were rinsed repeatedly with sterile water and then, crushed aseptically. A quantity of $1 \mathrm{~g}(1 \mathrm{~mL})$ of rhizosphere soil or root extract (the root extract was obtained by maceration of $100 \mathrm{~g}$ of root in 100 $\mathrm{mL}$ of saline solution), respectively from each of the collected samples was mixed in $9 \mathrm{~mL}$ of sterile saline solution $\left(\mathrm{NaCl}_{2} 0.85 \%\right)$. Consecutive dilutions were made (1:1000 and 1:10 000). One hundred $\mu \mathrm{L}$ of the last dilution were placed on Luria Bertani (LB) agar plates and incubated at $37^{\circ} \mathrm{C}$ for $48 \mathrm{~h}$. Colonies differing in morphological characteristics were isolated.

\section{Determination of the plant growth promotion traits}

Nitrogen fixation was determined on nutrient agar $(\mathrm{Nfb})$ by the method of Weber et al. (1999). One hundred $\mu \mathrm{L}$ of the consecutive dilutions 1:1000 and 1:10000 from rhizosphere and roots were streaked on $\mathrm{Nfb}$ plates, incubated at $30^{\circ} \mathrm{C}$ for $72 \mathrm{~h}$. Indole acetic acid (IAA) production was estimated by inoculating a bacterial suspension in $3 \mathrm{~mL}$ of Luria Bertani (LB) broth, containing L-tryptophan $(100 \mu \mathrm{g} / \mathrm{mL})$ and incubated at $30^{\circ} \mathrm{C}$ for $24 \mathrm{~h}$. IAA concentration in the supernatant culture was estimated by the Salkowsky reagent (Glickmann and Dessaux 1995, Gordon and Weber 1951). Gibberellins production was inferred by the quality method of Graham and Henderson (1961).
The method consists of rating visually the change in color on the culture supernatant using the Folling-Wu reagent from yellow to blue or green. Siderophore production was detected on nutrient agar fluorescein $(\mathrm{F})$.

Bacterial suspension was inoculated on agar $\mathrm{F}$ plates at $30{ }^{\circ} \mathrm{C}$ for 7 days, and then the green fluorescent color was visualized in ultraviolet light (King et al. 1954). Qualitative estimation of phosphate (P) solubilization was done by inoculating bacterial suspension on agar National Botanical Research Institute's phosphate growth medium (NBRIP) and incubating it at $30^{\circ} \mathrm{C}$ for seven days. The soluble $\mathrm{P}$ was visualized by calculating the size of the halo produced (Murphy and Riley 1962, Mehta and Nautiyal 2001).

\section{Morphological and biochemical characterization}

Individual cultures growing on nutrient agar at $30{ }^{\circ} \mathrm{C}$ were examined for their morphological and biochemical features. Gram staining was performed with exponential growing cultures. Urease, oxidase, mobility, citrate production, decarboxylase assay, and catalase tests were done with standard protocols as described in MacFaddin's manual of identification of bacteria (MacFaddin 2000). Identification of Gram positive bacteria was determined and compared by VITEK2 compact (bioMérieux).

\section{RESULTS AND DISCUSSION}

\section{Isolation and determination of plant growth pro- moted by rhizobacteria traits}

One hundred and forty three rizhobacterial isolates were obtained from soil and roots of creole and ungraded corn crops in the three communities surveyed. The screening of the bacterial isolates for determination of the plant growth promotion traits resulted in the isolation of 54 strains with multi-trait activity ( 28 of Sabanillas, 11 from Tixtla and 15 from Tlacoapa). Such screening was done, first on the basis of the growth obtained on Nfb agar plates, which emphasizes nitrogen-fixing activity. Further analyzes showed other growth promoting traits, such as siderophore production, phosphate solubilization, indole acetic acid production and gibberellins production.

Regarding the bacteria isolated from Sabanillas, Guerrero, only eight of the 28 isolates showed nitrogen fixing activity, 11 solubilized phosphate, 11 produced gibberellins, 21 produced auxins and 20 produced siderophores. From these isolates, we determined the presence of the strain $35 \mathrm{FF}$ corresponding to Pseudomonas fluorescens. This species proved high aptitude to promote growth in the plants, since 
it showed an excellent performance, such as nitrogen fixation, siderophores production, solubilization of phosphate, as well as auxins and gibberellins production (Table I). Due to the capabilities of these bacteria, consortiums can be developed and field tests can be performed. The latter with the porpuse to use them in the industrial area to manufacture and commercialize biofertilizers to replace chemical fertilizers.

From the isolates from Tixtla, Guerrero it was found that only eight of the 11 isolates showed nitrogen-fixing activity, six solubilized phosphate, all of them produced gibberellins and resulted negative for the siderophores test (Table II).

In the Tlacoapa region it was found that all isolates produced gibberellins and fixed nitrogen but only 10 of the 15 isolates solubilized phosphate and 8 produced auxins. Additionally, all strains resulted negative for the siderophores test (Table III).
The data showed that the strains $35 \mathrm{FF}, 46 \mathrm{FF}$, MR-LB, 6 MR-F isolates from Sabanillas and Tixtla, Guerrero and 2 CS-LB, 1 CR-F, A CR-F, 2 CR-F, 4 CR-F, 5 CR-F isolates from Tlacoapa, Guerrero have multi-trait activity, which is extremely useful for different plant growth promoting (PGP) activity.

\section{Biochemical characterization}

Isolated strains with more than one plant growth promoting trait were subjected to Gram staining to determine their structure and morphology. Fifty of these bacteria are Gram-negative and four of them are Gram positive. Metabolic properties by observing their response to diverse biochemical reactions for carbohydrate and by other additional tests such as, methyl red, voges proskauer, citrate test, catalase, oxidase activity, malonate, ortho-nitrophenylgalactopyranoside (ONPG), arginine, glucose, arabinose,

TABLE I. PLANT GROWTH TRAITS, PROMOTING ISOLATE BACTERIA STRAINS FROM SABANILLAS, GUERRERO

\begin{tabular}{|c|c|c|c|c|c|c|}
\hline Strains & $\begin{array}{l}\text { Nitrogen } \\
\text { fixation }\end{array}$ & Siderophores & $\begin{array}{c}\text { Solubilization } \\
\text { of phosphate }\end{array}$ & Auxins & Gibberellins & Specie \\
\hline $24 \mathrm{FF}$ & & $\checkmark$ & $\checkmark$ & $\checkmark$ & $\checkmark$ & Enterobacter cloacae \\
\hline $30 \mathrm{FF}$ & & & $\checkmark$ & & & Enterobacter cloacae \\
\hline $31 \mathrm{FF}$ & & & $\checkmark$ & & & Enterobacter cloacae \\
\hline $52 \mathrm{FF}$ & & $\checkmark$ & & $\checkmark$ & & Enterobacter cloacae \\
\hline NFB 19 & $\checkmark$ & & & $\checkmark$ & & Enterobacter cloacae \\
\hline NFB 4 & $\checkmark$ & & & & $\checkmark$ & Klebsiella varicola \\
\hline $46 \mathrm{FF}$ & $\checkmark$ & $\checkmark$ & & $\checkmark$ & $\checkmark$ & Klebsiella varicola \\
\hline $27 \mathrm{FF}$ & & $\checkmark$ & $\checkmark$ & $\checkmark$ & & Pantoea agglomerans \\
\hline NFB 8 & $\checkmark$ & & & $\checkmark$ & & Pantoea agglomerans \\
\hline $49 \mathrm{FF}$ & & $\checkmark$ & $\checkmark$ & & & Pseudomonas aeruginosa \\
\hline $42 \mathrm{FF}$ & & $\checkmark$ & & $\checkmark$ & & Pseudomonas aeruginosa \\
\hline $36 \mathrm{FF}$ & & $\checkmark$ & & $\checkmark$ & & Pseudomonas aeruginosa \\
\hline NFB 3 & $\checkmark$ & & & $\checkmark$ & & Pseudomonas aureginosa \\
\hline $35 \mathrm{FF}$ & $\checkmark$ & $\checkmark$ & $\checkmark$ & $\checkmark$ & $\checkmark$ & Pseudomonas fluorescens \\
\hline $28 \mathrm{FF}$ & & $\checkmark$ & & $\checkmark$ & $\checkmark$ & Pseudomonas fluorescens \\
\hline $26 \mathrm{FF}$ & & $\checkmark$ & & $\checkmark$ & & Pseudomonas fluorescens \\
\hline $43 \mathrm{FF}$ & & $\checkmark$ & & $\checkmark$ & & Pseudomonas fluorescens \\
\hline $37 \mathrm{FF}$ & & $\checkmark$ & & $\checkmark$ & $\checkmark$ & Pseudomonas putida \\
\hline $21 \mathrm{FF}$ & & $\checkmark$ & & $\checkmark$ & $\checkmark$ & Pseudomonas sp. \\
\hline $59 \mathrm{FF}$ & & $\checkmark$ & $\checkmark$ & $\checkmark$ & & Pseudomonas sp. \\
\hline $60 \mathrm{FF}$ & & $\checkmark$ & $\checkmark$ & $\checkmark$ & & Pseudomonas sp. \\
\hline $5 \mathrm{FF}$ & & $\checkmark$ & $\checkmark$ & $\checkmark$ & & Pseudomonas sp. \\
\hline $63 \mathrm{FF}$ & & $\checkmark$ & & & $\checkmark$ & Serratia marcescens \\
\hline NFB 18 & $\checkmark$ & & & & $\checkmark$ & Staphylococcus aureus \\
\hline $22 \mathrm{FF}$ & & $\checkmark$ & $\checkmark$ & $\checkmark$ & & Staphylococcus aureus \\
\hline NFB 15 & $\checkmark$ & & & & $\checkmark$ & Staphylococcus aureus \\
\hline $11 \mathrm{FF}$ & & $\checkmark$ & $\checkmark$ & $\checkmark$ & & Staphylococcus aureus \\
\hline $7 \mathrm{FF}$ & & $\checkmark$ & & $\checkmark$ & $\checkmark$ & Staphylococcus sp. \\
\hline
\end{tabular}

All tests were done in duplicate. ( ), No activity, $(\checkmark)$, activity. FF = fluorescein-fluorescein, NFB = nitrogen fixing bacteria. The number corresponds to the number of the strain isolated in the respective medium. 
TABLE II. PLANT GROWTH TRAITS, PROMOTING ISOLATE BACTERIA STRAINS FROM TIXTLA, GUERRERO

\begin{tabular}{|c|c|c|c|c|c|}
\hline Strains & $\begin{array}{l}\text { Nitrogen } \\
\text { fixation }\end{array}$ & $\begin{array}{l}\text { Solubilization } \\
\text { of phosphate }\end{array}$ & Auxins & Gibberellins & Specie \\
\hline 3 MR-LB & $\checkmark$ & & & $\checkmark$ & Acinetobacter lwoffii johnsonii \\
\hline 3 MS-LB & & $\checkmark$ & $\checkmark$ & $\checkmark$ & Burkholderia pseudomallei \\
\hline $5 \mathrm{MS}-\mathrm{LB}$ & & $\checkmark$ & $\checkmark$ & $\checkmark$ & Burkholderia pseudomallei \\
\hline 5 MR-LB & $\checkmark$ & & & $\checkmark$ & Citrobacter freundii \\
\hline 2MS-LB & & $\checkmark$ & $\checkmark$ & $\checkmark$ & Enterobacter aerogenes \\
\hline 3MR-F & $\checkmark$ & & $\checkmark$ & $\checkmark$ & Enterobacter aerogenes \\
\hline $6 \mathrm{MR}-\mathrm{F}$ & $\checkmark$ & $\checkmark$ & $\checkmark$ & $\checkmark$ & Enterobacter aerogenes \\
\hline 6 MR-LB & $\checkmark$ & & & $\checkmark$ & Enterobacter cloacae \\
\hline $2 \mathrm{MR}-\mathrm{F}$ & $\checkmark$ & $\checkmark$ & & $\checkmark$ & Enterobacter cloacae \\
\hline $1 \mathrm{MR}-\mathrm{LB}$ & $\checkmark$ & $\checkmark$ & $\checkmark$ & $\checkmark$ & Proteus mirabilis \\
\hline 2 MR-LB & $\checkmark$ & & & $\checkmark$ & Proteus mirabilis \\
\hline
\end{tabular}

All tests were done in duplicate. ( ), No activity, $(\checkmark)$, activity. MR-LB = maize root-Luria Bertani, MS-LB $=$ maize soil-Luria Bertani, MR-F $=$ maize root-fluorescein. The number corresponds to the number of the strain isolated in the respective medium.

trehalose, nitrate reduction and urease activity were also analyzed. Identification of the four Grampositive bacteria were determined and compared by VITEK 2 compact (bioMérieux). The outcomes of the assays revealed that the strains are related to the genus: Pseudomonas, Enterobacter, Serratia, Pantoea, Staphylococcus, Klebsiella, Burkholderia, Salmonella, Proteus, Acinetobacter, Citrobacter and Streptoccoccus (Tables I, II and III).
This variability might be due to different altitudes, soil types, humidity, $\mathrm{pH}$ and soil texture, which are important for the growth and microbial ecology of these organisms (Li et al. 2014, Wang et al. 2014, Yousuf et al. 2014). Other topics such as the use of agrochemicals and soil preparation could contribute to this variability (Tas et al. 2014). Whereas in the Tixtla region, agrochemicals as gramoxone, furadan and foley are commonly used, in Sabanillas the soil

TABLE III. PLANT GROWTH TRAITS, PROMOTING ISOLATE BACTERIA STRAINS FROM TLACOAPA, GUERRERO

\begin{tabular}{|c|c|c|c|c|c|}
\hline Strains & $\begin{array}{l}\text { Nitrogen } \\
\text { fixation }\end{array}$ & $\begin{array}{l}\text { Solubilization } \\
\text { of phosphate }\end{array}$ & Auxins & Gibberellins & Specie \\
\hline $4 \mathrm{CS}-\mathrm{F}$ & $\checkmark$ & & & $\checkmark$ & Acinetobacter lwoffii johnsonii \\
\hline $2 \mathrm{CR}-\mathrm{F}$ & $\checkmark$ & $\checkmark$ & $\checkmark$ & $\checkmark$ & Acinetobacter lwoffii johnsonii \\
\hline D CR-F & $\checkmark$ & $\checkmark$ & $\checkmark$ & & Acinetobacter lwoffii johnsonii \\
\hline 6 CS-LB & $\checkmark$ & & $\checkmark$ & $\checkmark$ & Acinetobacter lwoffii johnsonii \\
\hline 4 CR-LB & $\checkmark$ & & & $\checkmark$ & Enterobacter aerogenes \\
\hline 6 CR-LB & $\checkmark$ & & & $\checkmark$ & Enterobacter aerogenes \\
\hline 5 CR-LB & $\checkmark$ & & & $\checkmark$ & Enterobacter aerogenes \\
\hline $1 \mathrm{CR}-\mathrm{F}$ & $\checkmark$ & $\checkmark$ & $\checkmark$ & $\checkmark$ & Enterobacter aerogenes \\
\hline $4 \mathrm{CR}-\mathrm{F}$ & $\checkmark$ & $\checkmark$ & $\checkmark$ & $\checkmark$ & Enterobacter aerogenes \\
\hline 2 CS-LB & $\checkmark$ & $\checkmark$ & $\checkmark$ & $\checkmark$ & Enterobacter cloacae \\
\hline A CR-F & $\checkmark$ & $\checkmark$ & $\checkmark$ & $\checkmark$ & Enterobacter cloacae \\
\hline B CR-F & $\checkmark$ & $\checkmark$ & & $\checkmark$ & Enterobacter cloacae \\
\hline $3 \mathrm{CR}-\mathrm{F}$ & $\checkmark$ & $\checkmark$ & & $\checkmark$ & Enterobacter cloacae \\
\hline $1 \mathrm{CS}-\mathrm{F}$ & $\checkmark$ & $\checkmark$ & & $\checkmark$ & Staphylococcus lentus \\
\hline $5 \mathrm{CR}-\mathrm{F}$ & $\checkmark$ & $\checkmark$ & $\checkmark$ & $\checkmark$ & Streptoccoccus thoraltensis \\
\hline
\end{tabular}

All tests were done in duplicate. ( ), No activity, $(\checkmark)$, activity. CS-F $=$ creole soil fluorescein, CR-F $=$ creole root fluorescein, $\mathrm{CS}-\mathrm{LB}=$ creole soil Luria Bertani, $\mathrm{CR}-\mathrm{LB}=$ creole root Luria Bertani. The number corresponds to the number of the strain isolated in the respective medium. 
preparation consists in slashing and burning the foliage in the fields. Regarding Tlacoapa region, the use of agrochemicals and burning soil is alternated. Several bacteria from the genus Pseudomonas have been reported as PGP. The most representative and studied species is Pseudomonas fluorescens, which has multiple mechanisms as fluorescence (Zhang and Rainey 2013, Yin et al. 2014), phosphate solubilization (Babikova et al. 2014) and auxins and gibberellins production (Donati et al. 2013, Sauer et al. 2013, Colo et al. 2014). The same traits have been found in Pseudomonas putida (Ambardar et al. 2013, Islam et al. 2014). Species of the genus Enterobacter have been reported for its effect as PGP in rice crop (Patel et al. 2010) so, strains isolated from maize crops could be as effective as those reported for other crops. Within the collection we identified Klebsiella, by its production of adhesins, siderophores, lipopolysaccharide, and its ability to fix nitrogen, it could be considered within the PGP. Pantoea is a phosphate solubilizing bacterium that could increase the concentration of phosphorus in the leaf tissues. It is also a nitrogen-fixing bacterium that has been isolated from the inner part of the stems of sugarcane (Patel et al. 2010). Serratia marcensens is a motile bacillus that can grow at temperatures from 5 to $40^{\circ} \mathrm{C}$ in a $\mathrm{pH}$ of 5 to 9 . This enterobacteria mainly of clinical interest (Roy et al. 2014), was positive for siderophore and gibberellins production in low quantities, therefore it could be considered suitable to be used for PGP purposes. The genus Staphylococcus is a facultative anaerobic bacterium. The species of that genus have been of great importance for their detrimental effects on human health. However, there are no reports of this genus in the environment. For the positive effect of PGPR to show, it is necessary that these bacteria colonize and induce rapid seed germination, as well as root growth in the area called sphermatofera-rhizosphere because there is where the mineral-nutrient exchange takes place (Bhardwaj et al. 2014).

\section{CONCLUSION}

In this study the 54 strains of bacteria detected in these socio-environmental contexts, represent an opportunity to obtain biofertilizers through the synthesis of the bacterial products, for instance the auxins and the gibberellins. Besides, the formation of consortia and the synthesis of their common products can be as well used as biofertilizers, which represent the opportunity to avoid risks when using pesticides in excess. In that sense, the biotechnology can be employed to promote the growth of plants, such as seed germination and root elongation, in a faster time.

\section{ACKNOWLEDGMENTS}

The authors are grateful to Mr. Augusto Rojas Aparicio, Ms. Zuleyma Flores Rangel, Ms. Edith Martínez Telumbres, Ms. Eva Espinoza and Mr. Alejandro Ayala for their excellent technical assistance.

The authors declare that there is no conflict of interests for the publication of this research paper.

\section{REFERENCES}

Adesemoye A. O. and Kloepper J. W. (2009). Plantmicrobes interactions in enhanced fertilizer-use efficiency. Appl. Microbiol. Biotechnol. 85, 1-12.

DOI: $10.1007 / \mathrm{s} 00253-009-2196-0$

Ambardar S. and Vakhlu J. (2013). Plant growth promoting bacteria from Crocus sativus rhizosphere. World J. Microbiol. Biotechnol. 29, 2271-9.

DOI: $10.1007 / \mathrm{s} 11274-013-1393-2$

Babikova Z., Gilbert L., Randall K. C., Bruce T. J., Pickett J. A. and Johnson D. (2014). Increasing phosphorus supply is not the mechanism by which arbuscular mycorrhiza increase attractiveness of bean (Vicia faba) to aphids. J. Exp. Bot. 65, 5231-41.

DOI: $10.1093 / \mathrm{jxb} / \mathrm{eru} 283$

Bhardwaj D., Ansari M. W., Sahoo R. K. and Tuteja N. (2014). Biofertilizers function as key player in sustainable agriculture by improving soil fertility, plant tolerance and crop productivity. Microb. Cell Fact. 13, 66. DOI: $10.1186 / 1475-2859-13-66$

Bharucha U., Patel K. and Trivedi U. B. (2013). Optimization of indole acetic acid production by Pseudomonas putida UB1 and its effect as plant growth-promoting rhizobacteria on mustard (Brassica nigra). Agric. Res. 2, 215-221. DOI: 10.1007/s40003-013-0065-7

Colo J., Hajnal-Jafari T. I., Duric S., Stamenov D. and Hamidovic S. (2014). Plant growth promotion rhizobacteria in onion production. Pol. J. Microbiol. 63, 83-8.

Di Salvo L. P., Silva E., Teixeira K. R., Cote R. E., Pereyra M. A. and García de Salamone I. E. (2014). Physiological and biochemical characterization of Azospirillum brasilense strains commonly used as plant growthpromoting rhizobacteria. J. Basic Microbiol. 54, 131021. DOI: $10.1002 /$ jobm. 201400135

Dimkpa C., Weinand T. and Asch F. (2009). Plant-rhizobacteria interactions alleviate abiotic stress conditions. 
Plant Cell Environ. 32, 1682-94.

DOI: $10.1111 / \mathrm{j} .1365-3040.2009 .02028 . x$

Donati A. J., Lee H. I., Leveau J. H. and Chang W. S. (2013). Effects of indole-3-acetic acid on the transcriptional activities and stress tolerance of Bradyrhizobium japonicum. PLoS One 8, e76559.

DOI: 10.1371/journal.pone.0076559

Glickmann E. and Dessaux Y. (1995). A critical examination of the specificity of the salkowski reagent for indolic compounds produced by phytopathogenic bacteria. Appl. Environ. Microbiol. 61, 793-6.

Gordon S. A. and Weber R. P. (1951). Colorimetric estimation of indoleacetic acid. Plant Physiol. 26, 192-5.

Graham H. D. and Henderson J. H. (1961). Reaction of gibberellic acid and gibberellins with Folin-Wu phosphomolybdic acid reagent and its use for quantitative assay. Plant Physiol. 36, 405-408.

Gupta A., Gopal M., Thomas G. V., Manikandan V., Gajewski J., Thomas G., Seshagiri S., Schuster S. C., Rajesh P. and Gupta R. (2014). Whole genome sequencing and analysis of plant growth promoting bacteria isolated from the rhizosphere of plantation crops coconut, cocoa and arecanut. PLoS One 9, e104259. DOI: 10.1371/journal.pone.0104259

Hernández-Flores G., Poggi-Varaldo H.M., SolorzaFeria O., Ponce-Noyola M.T., Romero-Castañón T., Rinderknecht-Seijas N. and Galíndez-Mayer J. (2015a). Characteristics of a single chamber microbial fuel cell equipped with a low cost membrane. Int. J. Hydrogen Energy 40, 17380-17387.

DOI: 10.1016/j.ijhydene.2015.10.024

Hernández-Flores G., Poggi-Varaldo H.M., Solorza-Feria O., Ponce Noyola M.T., Romero-Castañón T. and Rinderknecht-Seijas N. (2015b). Improvement of microbial fuel cell performance by selection of anodic materials and enrichment of inoculum. J. New. Mat. Electrochem. Systems. 18, 121-129.

Islam F., Yasmeen T., Ali Q., Ali S., Arif M. S., Hussain S. and Rizvi H. (2014). Influence of Pseudomonas aeruginosa as PGPR on oxidative stress tolerance in wheat under Zn stress. Ecotoxicol. Environ. Saf. 104, 285-93. DOI: 10.1016/j.ecoenv.2014.03.008

King E. O., Ward M. K. and Raney D. E. (1954). Two simple media for the demonstration of pyocyanin and fluorescin. J. Lab Clin. Med. 44, 301-7.

Li Y., Ying Y. and Ding W. (2014). Dynamics of Panax ginseng Rhizospheric Soil Microbial Community and Their Metabolic Function. Evid. Based Complement. Alternat. Med. 2014, 160373.

DOI: $10.1155 / 2014 / 160373$

Labra-Cardon D., Guerrero-Zúñiga L.A., Rodríguez-Tovar A.V., Montes-Villafán S., Pérez-Jiménez S. and Rodríguez-Dorantes A. (2012). Respuesta de crecimiento y tolerancia a metales pesados de Cyperus elegans y Echinochloa polystachya inoculadas con una rizobacteria aislada de un suelo contaminado con hidrocarburos derivados del petróleo. Rev. Int. Contam. Ambie. 28, 7-16.

Lopez-Bucio J., Campos-Cuevas J. C., HernándezCalderón E., Velásquez-Becerra C., Farias-Rodriguez R., Macias-Rodriguez L. I. and Valencia-Cantero E. (2007). Bacillus megaterium rhizobacteria promote growth and alter root-system architecture through an auxin- and ethylene-independent signaling mechanism in Arabidopsis thaliana. Mol. Plant Microbe Interact. 20, 207-17. DOI: 10.1094/MPMI-20-2-0207

López-Ortiz C., Ferrera-Cerrato R., Alarcón A., Almaraz J.J., Martínez-Romero E. and Mendoza-López M.R. (2012). Establecimiento y respuestas fisiológicas de la simbiosis Rhizobium tropici-Leucaena leucocephala en presencia de fenantreno y naftaleno. Rev. Int. Contam. Ambie. 28, 333-342.

Lugtenberg B. and Kamilova F. (2009). Plant-growthpromoting rhizobacteria. Annu. Rev. Microbiol. 63, 541-56.

MacFaddin J. F. (2000). Biochemical tests for identification of medical bacteria. 3rd ed. Lippincott Williams and Wilkins. Philadelphia, USA, 912 pp.

Mehta S. and Nautiyal C. S. (2001). An efficient method for qualitative screening of phosphate-solubilizing bacteria. Curr. Microbiol. 43, 51-6.

DOI: $10.1007 / \mathrm{s} 002840010259$

Moreira H., Marques A. P., Franco A. R., Rangel A. O. and Castro P. M. (2014). Phytomanagement of Cdcontaminated soils using maize (Zea mays L.) assisted by plant growth-promoting rhizobacteria. Environ. Sci. Pollut. Res. Int. 21, 9742-53.

DOI: $10.1007 / \mathrm{s} 11356-014-2848-1$

Murphy J. and Riley J. P. (1962). A modified single solution method for the determination of phosphate in natural waters. Anal. Chim. Acta. 27, 31-36.

Patel K. J., Vig S., Naresh Kumar G. and Archana G. (2010). Effect of transgenic rhizobacteria overexpressing Citrobacter braakii appA on phytate-P availability to mung bean plants. J. Microbiol. Biotechnol. 20, 1491-9.

Poupin M. J., Timmermann T., Vega A., Zuniga A. and González B. (2013). Effects of the plant growthpromoting bacterium Burkholderia phytofirmans PsJN throughout the life cycle of Arabidopsis thaliana. PLoS One 8, e69435. DOI: 10.1371/journal.pone.0069435

Romero-Ramírez Y., Rodríguez-Barrera M. A., Segura D., Hernández J. A., Toribio-Jiménez J., Hernández-Flores G., Martínez Galero N. X. and Castellanos-Escamilla M. (2016). Evaluation of polyhydroxyalkanoates producing bacteria isolated from soils with wastes of Cocos nucifera. Rev. Int. Contam. Ambie. Accepted 
for the special issue on Biotecnología e Ingeniería Ambientales.

Roy P., Ahmed N. H. and Grover R. K. (2014). Nonpigmented strain of Serratia marcescens: an unusual pathogen causing pulmonary infection in a patient with malignancy. J Clin. Diagn. Res. 8, DD05-6.

DOI: $10.7860 / \mathrm{JCDR} / 2014 / 8629.4513$

SAGARPA-SIAP (2012). El maíz en Guerrero. Agenda de Innovación Guerrero. Fundación Produce de Guerrero. Maíz. Secretaría de Agricultura, Ganadería, Desarrollo Rural, Pesca y Alimentación- Servicio de Información Agroalimentaria y Pesquera. Chilpancingo, Guerrero, Mexico, 145 pp.

Sauer M., Robert S. and Kleine-Vehn J. (2013). Auxin: Simply complicated. J. Exp. Bot. 64, 2565-77.

DOI: $10.1093 / \mathrm{jxb} / \mathrm{ert} 139$

Schwachtje J., Karojet S., Thormahlen I., Bernholz C., Kunz S., Brouwer S., Schwochow M., Kohl K. and van Dongen J. T. (2011). A naturally associated rhizobacterium of Arabidopsis thaliana induces a starvationlike transcriptional response while promoting growth. PLoS One 6, e29382.

DOI: 10.1371/journal.pone.0029382

Shim J., Babu A. G., Velmurugan P., Shea P. J. and Oh B. T. (2014). Pseudomonas fluorescens JH 70-4 promotes pb stabilization and early seedling growth of sudan grass in contaminated mining site soil. Environ. Technol. 35, 2589-96. DOI: 10.1080/09593330.2014.913691

Tas N., Prestat E., McFarland J. W., Wickland K. P., Knight R., Berhe A. A., Jorgenson T., Waldrop M. P. and Jansson J. K. (2014). Impact of fire on active layer and permafrost microbial communities and metagenomes in an upland Alaskan boreal forest. ISME. J. 8, 190419. DOI: 10.1038 /ismej.2014.36

Vacheron J., Desbrosses G., Bouffaud M. L., Touraine B., Moenne-Loccoz Y., Muller D., Legendre L., Wisniewski-Dye F. and Prigent-Combaret C. (2013). Plant growth-promoting rhizobacteria and root system functioning. Front. Plant. Sci. 4, 356.

DOI: $10.3389 /$ fpls.2013.00356
Wang N., Wang M., Li S., Sui X., Han S. and Feng F. (2014). Effects of variation in precipitation on the distribution of soil bacterial diversity in the primitive Korean pine and broadleaved forests. World. J. Microbiol. Biotechnol. 30, 2975-84. DOI: $10.1007 / \mathrm{s} 11274-014-1725-\mathrm{x}$

Weber O. B., Baldani V. L. D., Teixeira K. R. d. S., Kirchhof G., Baldani J. I. and Dobereiner J. (1999). Isolation and characterization of diazotrophic bacteria from banana and pineapple plants. Plant and Soil 210, 103-113.

Yadegari M., Rahmani H. A., Noormohammadi G. and Ayneband A. (2008). Evaluation of bean (Phaseolus vulgaris) seeds inoculation with Rhizobium phaseoli and plant growth promoting rhizobacteria on yield and yield components. Pak. J. Biol. Sci. 11, 1935-9.

Yang J., Kloepper J. W. and Ryu C. M. (2009). Rhizosphere bacteria help plants tolerate abiotic stress. Trends. Plant. Sci. 14, 1-4. DOI: 10.1016/j.tplants.2008.10.004

Yin K., Zhang W. and Chen L. (2014). Pyoverdine secreted by Pseudomonas aeruginosa as a biological recognition element for the fluorescent detection of furazolidone. Biosens. Bioelectron. 51, 90-6. DOI: 10.1016/j.bios.2013.07.038

Yousuf B., Kumar R., Mishra A. and Jha B. (2014). Differential distribution and abundance of diazotrophic bacterial communities across different soil niches using a gene-targeted clone library approach. FEMS. Microbiol. Lett. 360, 117-25.

DOI: 10.1111/1574-6968.12593

Zhang X. X. and Rainey P. B. (2013). Exploring the sociobiology of pyoverdin-producing Pseudomonas. Evolution 67, 3161-74. DOI: 10.1111/evo.12183

Zulueta-Rodríguez R., Córdoba-Matson M. V., HernándezMontiel L. G., Murillo-Amador B., Rueda-Puente E. and Lara L. (2014). Effect of Pseudomonas putida on growth and anthocyanin pigment in two poinsettia (Euphorbia pulcherrima) cultivars. The Scientific World Journal 2014, 810192.

DOI: $10.1155 / 2014 / 810192$ 